\title{
DEBATES
}

\section{Putnam's instrument revisited. The community network of the industrial districts and a new proxy of social capital}

\author{
Instrumento de Putnam revisitado. A rede comunitária de distritos \\ industriais e um novo indicador do capital social
}

\section{Luca Andriani}

\begin{abstract}
This paper proposes a new proxy of social capital based on the regional density of industrial districts. The advantage of this new proxy is to better deal, at least conceptually, with the main three problems related to the PI advanced by Paldam (2000) which are: the definition of voluntary associations, the intensity of the contacts and the so called "Benignness-weight problem". In our analysis we show an empirical comparison between the behaviour of our index and that one of the Putnam Instrument across the Italian regions. To do so we use regional data in the 2001 from the Italian National Bureau of Statistics (ISTAT). One of the interesting results from the empirical application is that the new proxy and the Putnam's instruments present similar patterns, even though with some exceptions.
\end{abstract}

\section{Keywords}

Social Capital; Industrial Districts; Italian Regions.

\section{Resumo}

Esse artigo propóe um novo indicador do capital social baseado na densidade regional dos distritos industriais. A vantagem desse novo indicador é lidar melhor, pelo menos conceitualmente, com os três problemas principais relacionados com PI, previstos por Paldam (2000), que são: a definição de associaçôes voluntárias, a intensidade de contatos e o chamado "Problema do peso da bondade". Em nossa análise, mostramos uma comparação empírica entre o comportamento do nosso índice e um dos Instrumentos de Putnam em todas as regióes italianas. Para tanto, utilizamos dados regionais de 2001 do Instituto Nacional de Estatísticas da Itália (ISTAT). Um dos resultados interessantes da aplicação empírica é que o novo indicador e os instrumentos de Putnam apresentam padróes semelhantes, mesmo que com algumas exceçóes.

\section{Palavras-chave}

Capital Social; Distrito Industrial; Regióes Italianas. 


\section{Introduction 1}

Within the family of the social capital theorists it is generally accepted the idea that Social capital (SC) describes the pattern and intensity of networks among people and the shared values which arise from those networks. Greater interaction between people generates a greater sense of community spirit which, in the best scenario, is likely to generate and maintain a high level of generalised social trust inside the community. Putnam (2000, p. 19), for instance, defines social capital as connections among individuals which imply a system of social networks and the norms of reciprocity and trustworthiness that arise from them. In that sense social capital is closely related to what some has called "civic virtue." The difference is that "social capital" draws attention to the fact that civic virtue is most powerful when embedded in a network of reciprocal social relations. However, "a society of many virtuous but isolated individuals is not necessarily rich in social capital" (PUTNAM, 2000 , p. 19). In order to spread this sense of "civic virtue" associational activity becomes one of the key elements. Individuals facing a more intensive associational life hold a more diversified network and develop a spirit of civic engagement that increases the respect of the social norms by the members of the network, intensifies a system of reciprocity and trust and raises the community's reputation (PUTNAM 1993). In Bourdieu's (1983/1986, p. 248) view "Social capital is the aggregate of the actual or potential resources which are linked to possession of a durable network of more or less institutionalized relationships of mutual acquaintance and recognition". In other words, social capital is made up of social obligations and connections within members in a group (LIN, 2001).

A common message from the industrial and regional economic literature is that generalised trust and socially internalised community norms are two essential elements for the industrial districts to become vital actors in the regional and national economy (LEONARDI, 1995; DEI OTTATI, 1994; SFORZI 2002 just to mention few of them). In their seminal work about social capital and institutional and economic performance in Italy, Putnam et al. (1993, p. 160) point out that "Between the two Italies exists a Third Italy based on a diffused economy". Where the expression "two Italies" refers to the industrialised North and the backwardness of the southern regions, the "Third Italy" refers to the phenomenon of the industrial districts. The industrial district (ID) can be defined as a local system characterised by

\footnotetext{
${ }^{1}$ We are grateful to John Driffill, Ron Smith, Klaus Nielsen, Asimina Christoforou, Kim Mannemar Sonderskov and Martin Paldam. Usual Caveats apply.

${ }^{2}$ The term "Third Italy" has been used the first time by the sociologist Bagnasco (1977).
} 
the active co-presence of a human community and a dominant industry consisting of a set of small independent firms specialising in different phases of the same production process (SFORZI, 2002). This system is characterised by long-term socio-economic relationships among local firms involving trust, competition and collaboration and the role of local institutions (GUERRIERI and PIETROBELLI, 2000). These particular characteristics lead us to consider the ID a community working as a "social capital conductor". More precisely, we consider the industrial district a type of "community" in which the respect of norms of reciprocity, the trustworthiness and the mutual cooperation are highly developed. Because of the nature of this particular community, its members tend to build, develop and maintain an important system of capital of connections that facilitates and promotes the level of civic engagement inside the district. Given this initial framework, we argue that higher regional density of industrial district communities should imply a higher level of social capital in the region. The aim of this paper is to propose a new proxy of social capital based on the density of the ID network at the regional level. The methodology used is very similar to that one formalised by Paldam (2000) in order to construct the Putnam's instrument (PI). This new proxy should, at least conceptually, better deal with the main three problems related to the PI advanced by Paldam (2000) which are: the definition of voluntary associations, the intensity of the contacts and the so called "Benignness-weight problem". In our analysis we will compare the behaviour of our index with that one of the PI across the Italian regions. We find the two proxies to be positively correlated and to present similar patterns even though with some exceptions. The paper is developed through the following structure.

Section 2 relates the industrial districts with the importance of network and embeddedness; section 3 describes the Italianate version of the ID and its internalised mechanisms of cooperation; section 4 presents the new proxy of social capital and its methodological construction; section 6 shows the empirical results of the applications of the new proxy and the Putnam's instruments; section 7 concludes.

\section{Industrial Districts between Network and Embeddedne}

Most of the post-Coleman (1990) literature has viewed social capital as a community-level attribute (GLAESER, et al. 2003). Actually, social capital theorists stress the idea that network and embeddedness represent the framework where social capital develops (LIN, 2001; PUTNAM, et al. 1993; PUTNAM, 2000; SABATINI, 2005). If the concept of network is very popular in social sciences, that one of embeddedness might need a brief description. The concept of "embeddedness" is 
often used to understand economic actions inside social structures (GRANOVETTER, 1973 e 1985). Most recently, Uzzi (1997, 1998) used this concept to analyse inter-firm relationships. More specifically, he identifies two forms of relationships: the arm's-length relationship based on the "one shot deal" and the embeddedness relationship, consisting of a more personal business relationship, or even better, a business friendship. The latter has three main components. The first component is trust, which is seen by the partners more under a heuristic ${ }^{3}$ approach rather than a typical self-interest approach. Trust is developed through extra efforts (called "favours") that are voluntarily given and reciprocated without any formal devices used to enforce this reciprocation (e.g. contracts, fines, overt sanctions...). Of course, trust can break down in case of repeated abuse by one part. The second component is the fine-grained information transfer. This is more than a matter of asset specific know how or reducing informational asymmetry between parties, because the social relationship imbues the information with veracity and meaning beyond its face value. The last component is characterised by the joint problemsolving arrangements. This problem-solving mechanism enables actors to coordinate functions and work out problems "on the fly". This refers to routines of negotiation and mutual adjustment that flexibly resolve problems. The mechanism implies that firms, in an embeddedness relationship, work through problems and get direct feedback, increasing learning and the discovery of new combinations. The result is a reduction of production errors and an increase in innovation.

The industrial districts (IDs) may represent a particular environment in which network and embedded resources are maintained and possibly grow over the time and among its members. In the Marshallian view ${ }^{4}$, industrial districts are characterised by small locally owned firms that make investments and production decision locally (MARKUSEN, 1996). This particular cluster of small and medium sized enterprises (SMEs) is integrated within the community where it is located. Hence, economic relations are likely to be influenced by social relations by facilitating, in this way, the building of a community whose elements (individuals, households, firms and local administration) share the same system of norms, values and original culture. This, in turn, facilitates the creation of a more consistent system of trust within the environment itself. By using a Marshallian expression, all the

\footnotetext{
${ }^{3}$ In the analysis of the trust the "traditional" self-interest approach supported by game theory studies is not considered the most correct one, especially for this kind of relationship. Instead, according to a heuristic approach, the author underlines the predilections to assume the best when interpreting another's motives and actions.

${ }^{4}$ Marshall is considered one of the pioneers who analysed industrial districts (MARKUSEN, 1996).
} 
members of this community benefit from the fact that "the secrets of industry are in the air".

\section{The Italianate Industrial District Between the "Custom of Reciprocal Co-Operation" and the "System of Mutual Information"}

In his theoretical work Harrison (1992) argues that the industrial district prototypes are more than a simple reassertion of agglomeration economies. By recalling the work of Granovetter (1985) on embeddedness and economic action, Harrison (1991) underlines the importance of social relationships and personal contacts inside the district. These repeated interactions between actors through continual formal and informal contracting and re-contracting facilitate the building of trust and mutual cooperation. The scenario depicted by Harrison (1991) is shown in figure 1 on the Marshallian industrial districts (MARKUSEN, 1996). Figure 1 shows the scenario depicted by Harrison (1991). The ID presents many small companies buying and selling from each other for eventual export outside the region. They need to purchase raw materials and business services from outside the area (on the left) and they sell to external markets (on the right). This mechanism requires the presence of ties between members belonging to different companies inside the district community which cause a system of competition and collaboration. Figure 1 easily gives the idea of an industrial district acting as a collective entrepreneur (PIETROBELLI, 2000 in BAGELLA and BECCHETTI, 2000): many small independent firms specialised in one or few phases of the production cycle that have well-established relationships among each other. 
Figure 1 - Marshallian's Industrial Districts (a la Markusen)

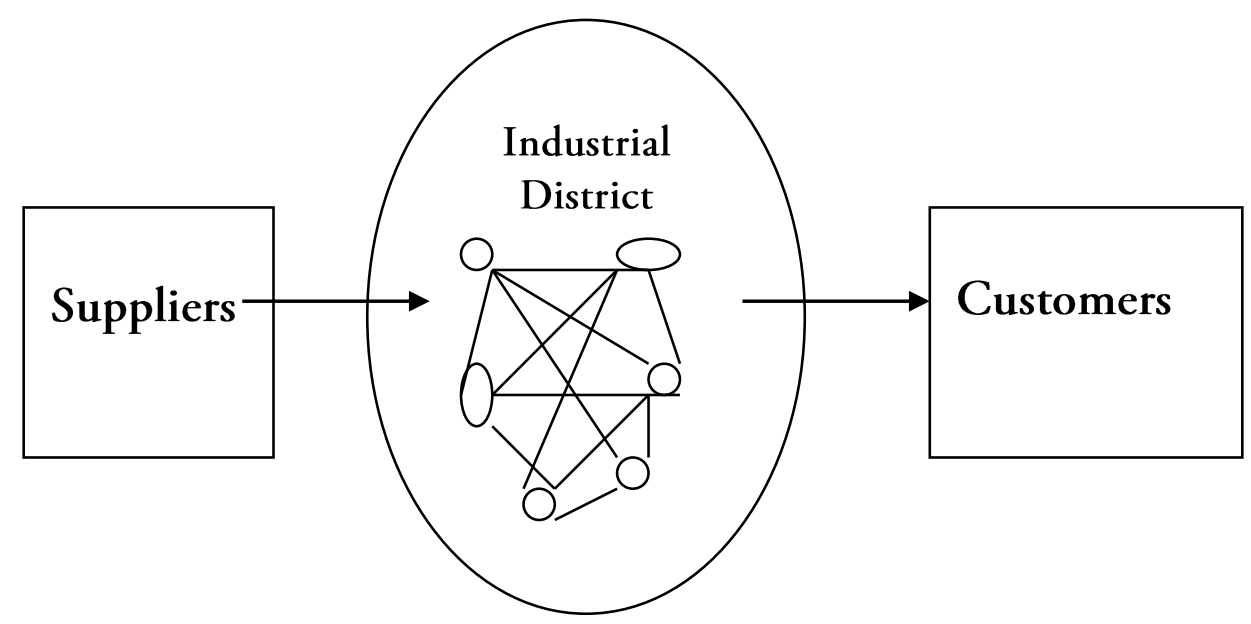

Source: Markusen (1996).

Table 1 shows the features of the Marshallian ID and the Italianate Version. From the table, it appears that the structure of the ID is based on small local companies that constantly trade among each other and that plan their investments locally. Moreover inside the districts the relationships are based on long-term non paper contracts. This identifies the ID as a long-term network with long term relationships that help to create an environment able to promote inter-firm cooperation (KNORRINGA and STAMMER, 1998). Conversely, time-limited agreements are only established in order to achieve a particular goal within a particular period of time. Using Uzzi's terminology, the relationships inside the districts are more of the type of embeddedness relationships rather than arm's-length relationships.

Markusen (1996, p. 299) underlines that "what makes the industrial districts so special and vibrant, in Marshall's account, is the nature and quality of the local labour market". This is based on two particular characteristics. Firstly the flexibility of the labour market inside the district where workers move from a firm to another keeping with them the acquired knowledge (human capital) and the relationship with the previous colleagues (capital of connections). Secondly, the workers commitments are towards the district and only subsequently towards the firms. This explains the 
low degree of (out)migration since the individual considers himself first a member of an embedded community endowed with a particular identity and culture, and only secondly a worker of a firm.

Table 1 - Marshallian and Italianate Industrial Districts

\begin{tabular}{|c|c|c|}
\hline \multicolumn{3}{|c|}{ Features of Marshallian and Italianate Industrial Districts (a la Markusen) } \\
\hline Features & Marshallian ID & Italianate Version \\
\hline Prevailing Mraket Structure & Local SMEs & Local SMEs \\
\hline Economies of Scale & Low & Low \\
\hline Intra-district Trade & Highly developed & Highly developed \\
\hline Key Investments & Local decision & Local decision \\
\hline Buyer-Producer Cooperation & & Important \\
\hline Regulation of Relationships & Long-term contracts & Long-term contracts \\
\hline Labour Market & $\begin{array}{l}\text { Internal to the ID highly } \\
\text { flexible }\end{array}$ & $\begin{array}{l}\text { Internal to the ID highly } \\
\text { flexible }\end{array}$ \\
\hline $\begin{array}{c}\text { Relationship External to the } \\
\text { District }\end{array}$ & $\begin{array}{c}\text { Low cooperation with firms } \\
\text { outside the district }\end{array}$ & $\begin{array}{c}\text { Low cooperation with firms } \\
\text { outside the district }\end{array}$ \\
\hline Workers' Commitment & $1^{\text {st }}$ with ID, $2^{\text {nd }}$ with enterprises & $1^{\text {st }}$ with ID, $2^{\text {nd }}$ with enterprises \\
\hline Labour Immigration & High & High \\
\hline Labour (out)migration & Low & Low \\
\hline Local Cultural Identity & Developed & Developed \\
\hline $\begin{array}{c}\text { Sources of Financing and } \\
\text { Technical Assistance }\end{array}$ & Internal to the ID & Internal to the ID \\
\hline Patient Capital* & Exists & Exists \\
\hline Personnel Exchanges & & High \\
\hline $\begin{array}{c}\text { Cooperation among } \\
\text { Competitors }\end{array}$ & & $\begin{array}{c}\text { High in order to share risk and } \\
\text { innovation }\end{array}$ \\
\hline Innovation & & $\begin{array}{c}\text { Disproportionate shares of } \\
\text { workers engaged in design and } \\
\text { innovation }\end{array}$ \\
\hline Local Trade Association & & Strong presence \\
\hline Local Government & & Important \\
\hline
\end{tabular}

Source: Integration between Markusen (1996) and Guerrieri-Pietrobelli (2000).

* Presence of financial institutions willing to take long-term risks, for the confidence and information they possess

A particular characteristic of Marshallian industrial districts is the presence of what is called "patient capital". This indicates local financial institutions, integrated within the ID, willing to take long-term risks because of a high level of inside information and trust in local firms. 
The Italianate version presents some extra features. First of all, there is cooperation between buyers and producers and among competitors (SAXENIAN, 1996). This implies on one hand that competitor firms share risks making the market more stable. On the other hand, the flow of information resulting from the tendency to cooperate and the ability to work together has a positive effect on the innovation capacity in the area (see SEXENIAN, 1996). As Guerrieri and Pietrobelli (2000) point out, most of the technological knowledge is tacit, complex and systemic. Therefore, frequent and informal personal contacts and exchanges represent crucial elements because innovation develops. Moreover, unlike Marshallian IDs, the Italianate version seems to imply a higher level of associational activities given the frequent contact between the firms and the local trade associations which provide not only technical support, but also physical and relational space for meetings and forums.

\section{The "Custom of Reciprocal Co-operation" and the "System of Mutual Information"}

The Italianate version shows that a system of strong and weak connections exists and that it facilitates the accumulation of these types of collective assets such as trust and information.

The mechanisms that facilitate the creation of this collective asset are described by Dei Ottati (1994) through the concept of "the custom of reciprocal cooperation". The analysis is based on three initial main points (or facts). Firstly, the labour mobility between firms reinforces the reciprocal interdependence and favours the perception of the human capital at the local industry as a kind of collective property. Secondly, because of the limited geographical dimension of the environment in which an ID grows, the local agents can easily observe and remember the past behaviour of the people with whom they have had previous business relations. Finally, due to the last point, in case of incorrect behaviour, the widespread possibility of punishing by withdrawing the willingness to conclude future transactions with them more a social disapproval represent a useful grim strategy. Therefore, the "custom of co-operation" (strictly linked with a long term network) helps to reproduce trust, reducing the demand for substitutes for trust and the need to monitor which, in turn, implies less direct costs (monitoring costs in primis) and the possibility to generate distrust.

The circulation of inside information, together with the relatively high level of trust, represents another collective resource of the industrial district. 
Figure 2 - Networks and embeddedness related to the Industrial Districts

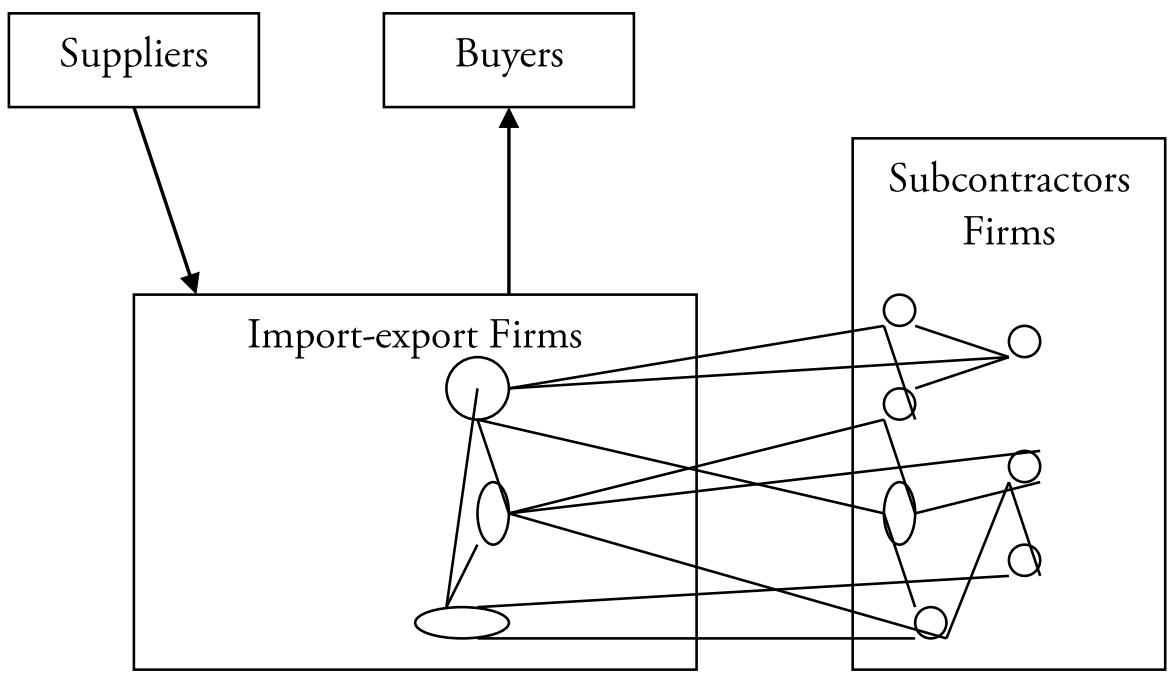

Source: Author's Reproduction.

As we have seen in Markusen's (1996) analysis, high level of mobility facilitates the flow of information among members. Moreover, Dei Ottati (1994) shows that there also exists a high level of what we call here "mutual information" among firms. This is facilitated by the co-existence of two main types of firms inside the district. The first type is represented by the companies that are generally specialised in buying and selling (or "import-export"). This means that they possess the information on end-market conditions. The second type refers to firms ("subcontractors") specialised in different phases of the production process that, therefore, possess information on the conditions of production. This scenario implies different types of information (about the market conditions, and about the production process) hold by different types of actors that, in turn, are responsible for different stages of the same "project". As a result this system of mutual information facilitates reciprocal co-operation inside the industrial district network by increasing, in this way, the capital of collective assets.

From the analysis made so far about the IDs we might probably derive a first general outcome. A district is a network with embedded resources (information for instance) where the connections among the actors (members and firms belonging to the district) are used constantly through mutual cooperation which may help to build an idiosyncratic system of mutual trust. If this is true, the industrial district may 
represent a network where the "capital of connections" is crucial not only for the single member but for the entire community.

\section{Putnam's Instrument and a New Social Capital Proxy}

Information and trust are vital for a network since they represent most of the network's "intangible" resources which might help the society to achieve either economic and social outcomes that are tangible (well-being, higher employment rate, innovation in terms of patents and products...) or intangible (sense of social security, sense of well-being, innovation in terms of tacit knowledge....). If information represents the primary resource that an individual or a group wants to achieve through the available "capital of connections", "trust" might be one of the engines that makes (at least partially) this system work.

Recalling Putnam (1993, 2000), networks and associational activities are important frameworks where social capital can take place and grow. This kind of approach is known in the literature as Putnam's Instrument PI (Paldam 2000). In analysing the difference in terms of governance, institutional performance and wellbeing between Northern and Southern Italy, Putnam et al.. (1993) consider the associational life as one of the crucial variables (other variables are newspaper readers, electoral turnout, preference voting patterns). In simple words, participation in voluntary organisations and social associations promotes among the members collective norms and trust which is fundamental for the production and the maintenance of the community's well-being. We are going to present the "instrument" by using the formalisation made by Paldam (2000).

Consider a region (or an area) and, hence, consider the population Ai belonging to that region. The associational activity inside the region is based on the density of voluntary organisations (VOs) that work locally. This density of VOs can be considered as a proxy of social capital. The process is the following.

Consider the following ingredients: $A i$ where $i=1,2, \ldots ., n$ is the population $\Pi=$ density of Voluntary Organisations (VOs) which is a proxy of SC (This is Putnam's instrument)

Two ways of deriving Putnam's index

1) by asking people how many organisations they belong to

2) by asking the organisations how many members they have

$1)=2$ ): the survey should give the same result. In case there is a difference, it is possible that this is due to missing observations or other interesting problems.

\section{First way}


$P i=$ a person belonging to $y i$ organisations

$$
\begin{gathered}
N=\sum_{i=1}^{n} y_{i} \text { for } i=1,2, \ldots, \mathrm{n} \text { people } \\
\Pi=\frac{N}{n}
\end{gathered}
$$

\section{Second way}

The organisation $j$ has zj members

$$
\begin{gathered}
M=\sum_{j=1}^{m} z_{j} \quad \text { for } j=1,2, \ldots, m \text { organisations } \\
\Pi=\frac{M}{n} \quad \text { hence } \\
\begin{array}{c}
1) \quad=2) \text { means that } \\
\Pi=\frac{N}{n}=\frac{M}{n}
\end{array}
\end{gathered}
$$

Note that in a homogeneous country, $\Pi$ may not likely vary much through the country.

Putnam's index is recognised as one of the principal SC proxies for at least three reasons. Firstly, it is easy to calculate (it is quite simple to construct). Secondly, it combines the element of "trust" with that of "cooperation". Finally, empirical evidence shows that it is "significant" (even though mainly at a correlation level), proving that there is a positive correlation between SC and economic performance (PUTNAM et al., 1993; PUTNAM, 2000; HELLIWELL PUTNAM, 1996).

However, the critics from the literature are based on three main problems connected with the index.

The first one is related to the definition of VOs. Some voluntary organisations are more business-oriented (Bs), some others are government organisations (GOs). Moreover, some of them change their status from GOs to 
NGOs (Non-government organisations) or from Bs to NGOs and vice versa creating confusions regarding the sample to use.

The second problem is related to the intensity of the contacts. One of the problems is to weight the index. Because several VOs exist with memberships that cost little in terms of times and do not demand intensive and frequent contacts, some people, holding a membership, may even not remember that they are members. Therefore each $\mathrm{VO}$ is weighted by the number of contacts that pi has with the organisation. This is not easy to verify or to calculate.

The final problem is related to what in the literature is called the "Benignness-weight problem". Some VOs are clearly non-benign such as violent organisations, criminal and racist organisations. They do not provide social benefits for the community (especially considering that one of the characteristics of the social capital system is the free exit. This is something not allowed in organisations such as the "Mafia" - See PALDAM, 2000).

\section{The Construction of a New Proxy of Social Capital Using the IDs}

Given the characteristics of the industrial districts, we consider the ID as a particular community and the workers inside the districts as members of this community. The idea is, therefore, to construct a new index by using the same structure and method applied in the Putnam's one.

Like with Putnam's instrument, we consider a population and the members of the IDs network rather than VOs one.

Before constructing our index we need to empirically define the ID network. We do so by using a standard model adopted by the ISTAT as well as in the industrial district literature (RUSSO and ROSSI, 2001; BAFFIGI, PAGNINI and QUINTILIANI, 1997; SFORZI, 2002). The Italian national territory is composed of twenty regions with their own "regional government" and administration and characterised by local labour systems (LLS). While the LLS are territorial grouping of municipalities statistically comparable, the IDs are LLS that meet particular industrial concentration criteria. The statistical process that the national census uses to identify the ID is based on four phases:

1. Identify LLS mainly manufacturing

2. Identify LLS mainly manufacturing whose industrial economy is based on SMEs

3. Identify the main industrial sub-sector (ex. textile) of these LLS

4. Identify the IDs 
These phases are described in more details below

1) Identify LLS mainly manufacturing

a) Compute the Concentration coefficient relative to the economic activity for each LLS

$$
\frac{\text { LLSn, ateco/ITAn, ateco }}{\text { LLSn,tot/ITAn, tot }}
$$

$L L S n$, ateco $=$ workers in each economic activity in a LLS

$I T A n$, ateco $=$ workers in each economic activity in Italy

ateco $=$ economic activity

$L L S$ n,tot $=$ total workers (in the good and service market) in a LLS

$I T A n, t o t=$ total workers (in the good and service market) in Italy

b) Compare the LLS with a coefficient in the manufacturing industry higher than the national mean in order to derive the dominant economic activity.

$$
[(L L S n, \text { ateco/ITAn, ateco })-(L L S n, \text { tot / ITAn,tot })]^{*} \text { ITAn, ateco }
$$

If the highest coefficient is related to the manufacturing industry, then the LLS is mainly manufacturing

2) Identify LLS mainly manufacturing whose industrial economy is based on SMEs

Consider three dimensional classes of enterprises

- $\quad$ Small size 0-49 workers

- $\quad$ Medium size 50-249 workers

- $\quad$ Big size over 249 workers

Compute the coefficient for each dimensional class

$$
\frac{\text { LLSn(class), man/ITAn(class), man }}{L L S n, \text { man/ITAn, } \text { man }}
$$


$L L S n$ (class), $\operatorname{man}=$ workers for each dimensional class in the manufacturing sector in the LLS

$\operatorname{ITAn}$ (class), $\operatorname{man}=$ workers for each dimensional class in the manufacturing sector in Italy

$L L S n, \operatorname{man}=$ workers in the manufacturing industry in a LLS

ITAn,man = workers in the manufacturing industry in Italy

3) Identify the main industrial sub-sector (ex. Textile) of these LLS

a) Compute the coefficient relative to each sub-sector (The census identifies 10 sub-sectors)

$$
\frac{L L S n, \operatorname{sub} / I T A n, s u b}{L L S n, \text { man/ITAn, man }}
$$

$L L S n, s u b=$ workers in each sub-sector in a manufacturing LLS

$I T A n, s u b=$ workers in each sub-sector in Italy

$L L S n$, man $=$ workers in the manufacturing sector in a manufacturing LLS

$I T A n$, man $=$ workers in the manufacturing sector in Italy

b) Compare the LLS with a coefficient greater than 1 in order to derive the dominant sub-sector.

$$
[(L L S n, s u b / I T A n, s u b)-(L L S n, \text { man/ITAn, man })]^{*} I T A n, s u b
$$

The highest coefficient identifies the sub-sector

\section{4) Identify the IDs}

Two conditions need to be satisfied

a) The level of employment of small firms operating in the LLS specialised manufacturing activity must be greater than 50\% of total employment in the same activity at the LLS level

$$
\frac{\operatorname{LLSn}(\text { sme }), s u b_{-} p}{\operatorname{LSSn}(\text { tot }), s u b_{-} p}>50 \%
$$


$L L S n(s m e), s u b \_p=$ workers in the principal sub-sector employed in the SMEs in a manufacturing LLS made by SMEs

$L L S n(t o t), s u b \_p=$ total workers in the principal sub-sector in a manufacturing LLS made by SMEs

b) In case there is only one medium companies in the clusters, then the number of the workers in the small companies has to be greater than the $50 \%$ of the number of the workers in the medium company (such that the industrial system is not polarised)

$$
\frac{\operatorname{LLSn}(\text { small }), \text { sub_p }}{\operatorname{LLSn}(\text { medium }), \text { sub_p }_{-}}>50 \%
$$

LLSn(small),sub_p = Workers for small companies in the main sub-sector in a manufacturing LLS made by SMEs

LLSn(medium)sub_p = workers for a medium company (when there is only one medium company in the industrial system) in a manufacturing LLS made by SMEs

Once identified the ID we can construct the social capital proxy by following the same structure of Putnam's index. Hence, we consider a socio-economic area, for instance a region. There exists a population of workers $j=1,2, \ldots, m$ which is the sum of all the workers belonging to the Local Labour System of the region. We want to know how many workers in the area work for the IDs. $d j$ industrial district has $l j$ workers

$$
\begin{aligned}
& L=\sum_{j=1}^{m} d_{j} \\
& \text { hence } \\
& \frac{L}{m}=\text { dind }
\end{aligned}
$$

\section{Dind and a Good Social Capital Indicator}

Because of the nature of the ID network, dind might solve, conceptually, the three problems mentioned before which are related to the Putnam's instrument. 
The first problem, the definition problem, will not occur, since the IDs are business-oriented and based on a common structure. Actually, the firms inside the IDs develop together the shape of this particular cluster industry according to the local system of values, norms and the market in and for which they work. However, the general structure with its system of links is extremely similar from one industrial district to another. In fact, in the literature, empirical works, especially at the macro level, do not distinguish between industrial districts (RUSSO and ROSSI, 2001; BAFFIGI, PAGNINI and QUINTILIANI, 1997). Because of this common structure they do not change nature or status as it might more likely happen to the VOs considered by Putnam.

The second problem, the intensity of the contacts, is solved by the production system of the ID itself. Within a district each firm is specialised in one or few phases of the same production and because of the system of "mutual cooperation" (DEI OTTATI, 1994) it does not have any incentive in free riding. Moreover, the "membership and the contacts" are represented by the work commitments that all the members respect on a daily basis in order to maximise the profit of their own firm or, in most of the case, to survive.

About the third problem, the "Benignness-weight problem" so far it does not seem that the IDs hide or are based on "shadow criminal organisations" therefore also this problem is voided.

Additionally, the dynamics of the "custom of reciprocal cooperation" and of the "mutual information" of Dei Ottati (1994) strongly support the idea that the proxy dind satisfies the trust-cooperation complex advanced by Paldam (2000).

This particular concept indicates that trust and cooperation are two interlinked elements that any social capital indicator should be able to satisfy somehow 5 . More formally Paldam (2000) expresses this interlink as it follows

$$
\text { Trust } \Leftrightarrow \text { ease of voluntary cooperation } \pm \mathrm{e}
$$

Where $e$ is a small error and the "ease of voluntary cooperation" indicates the ability of individuals to work together which also corresponds to the definition of social capital provided by Coleman (1988). Harder work, instead, is to define "trust". Literature on "trust" and social capital stress the importance of the so called

\footnotetext{
${ }^{5}$ Notice that in the literature it is still ambiguous whether these two concepts are causally linked one to each other. In Sonderskov's (2008) impression this link in the literature seems to be treated more as an assumption rather than a theoretical and/or empirical justification.
} 
"generalised trust" as the engine of the social capital mechanism (KNACK, 2002; PUTNAM, 2000; GUISO et al. 2004; WOOLCOCK, 1998 and 2001). "Generalised trust" is defined as the trust between the members of a community. As Sonderskov's (2008) underlines this should not be confused with the trust towards a specific individual in a specific situation. Rather it identifies the belief that the other members of the community in general are trustworthy. Coleman (1990) relates this term to the individual's standard estimate of the trustworthiness of other people in absence of any other information.

In the case of the community of the ID whether the cooperative behaviour of its member is driven by altruism or by cooperative self-interest is not analysed in this work. However, the internalisation of norms of cooperation inside the community and the dissemination of trust among its members provide conceptual robustness to our indicator.

\section{Putnam's Instrument and DIND in Italy: the Results of the Application}

The data used to construct the indicators (PI and DIND) derive from the " 8 th General Census on Industry and Industrial Districts 2001" (ISTAT, 2001) and from the report on "Voluntary Organisations in Italy 2001" (ISTAT, 2001). Figure 3 shows the net of the local labour systems characterising the industrial composition of Italy under the geographic perspective. Some of the LLS correspond to industrial districts. 
Figure 3 - Local Labour System in Italy 2001

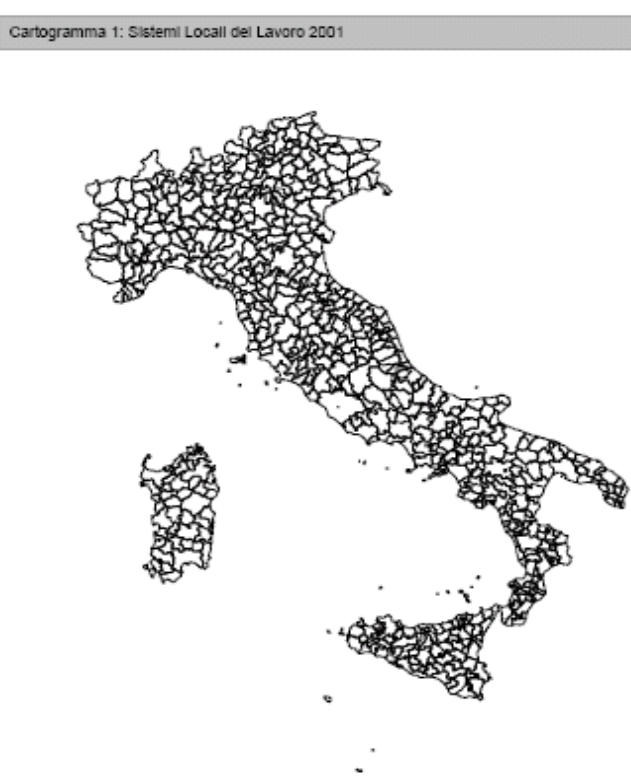

Source: " 8 th General Census on Industry and Services" (2001).

As we can see in figure 4, the distribution of the industrial districts is mainly concentrated on the Centre and on the North of the peninsula.

Table 2 may help in the general analysis. In Italy, according to the last Census, there are 156 industrial districts over 686 local labour systems. Italian territory is divided into 20 institutional and physical regions ${ }^{6}$ each of them with a "regional government" provided with the right to marginally employ some macroeconomic policies (such as expenditure in public goods, local fiscal policy, expenditure in regional investment on different forms of capital and so on).

The observations drawn by the ISTAT are 21 because of the division of the region of Trentino Alto Adige into Bolzano and Trento.

\footnotetext{
${ }^{6}$ Constitutionally Italy is divided in 20 regions, however the ISTAT decides to split the region Trentino Alto Adige into two "sub-regions" called "Province Autonome": Trento and Bolzano because of their socio-cultural-economic characteristics.
} 
Table 2 - Industrial Districts and Local labour Systems per regions 2001

\begin{tabular}{l|c|c|c|c}
\hline REGIONS & \multicolumn{2}{|c|}{ IDs } & \multicolumn{2}{c}{ LLS } \\
\hline Piemonte & N. Districts & Labour Units & N. LLS & Labour Units \\
\hline Valle d'Aosta & 12 & 297,034 & 37 & $1,652,362$ \\
\hline Lombardia & - & - & 3 & 51,568 \\
\hline Bolzano-Bozen & 27 & $1,745,042$ & 58 & $3,920,631$ \\
\hline Trento & - & - & 16 & 207,611 \\
\hline Veneto & 4 & 46,814 & 17 & 197,612 \\
\hline Friuli-Venezia Giulia & 22 & 861,546 & 34 & $1,896,143$ \\
\hline Liguria & 3 & 123,244 & 11 & 474,146 \\
\hline Emilia-Romagna & - & - & 16 & 537,251 \\
\hline Toscana & 13 & 574,432 & 41 & $1,755,422$ \\
\hline Umbria & 15 & 466,494 & 53 & $1,375,783$ \\
\hline Marche & 5 & 61,823 & 17 & 294,930 \\
\hline Lazio & 27 & 435,063 & 33 & 592,336 \\
\hline Abruzzo & 2 & 31,542 & 25 & $1,745,432$ \\
\hline Molise & 6 & 96,859 & 19 & 396,422 \\
\hline Campania & 2 & 4,307 & 9 & 88,222 \\
\hline Puglia & 6 & 26,177 & 54 & $1,267,384$ \\
\hline Basilicata & 8 & 144,096 & 44 & 940,182 \\
\hline Calabria & 1 & 9,927 & 19 & 152,103 \\
\hline Sicilia & - & - & 58 & 399,995 \\
\hline Sardegna & 2 & 3,236 & 77 & $1,034,949$ \\
\hline ITALIA & 1 & 2,085 & 45 & 430,072 \\
\hline Source: & 26 & $4,929,721$ & 686 & $19,410,556$ \\
\hline
\end{tabular}

Source: " 8 th General Census on Industry and Services" (2001).

We can immediately notice that four out of the 21 regions do not have industrial districts. Three of these regions are located in the North and only one in the South. All of these three northern regions are located near the borders: Liguria in the North-West coast neighbouring with France, the Valle d'Aosta neighbouring with France and Switzerland, Bolzano's inter-land with Austria. On the other hand, the region in the South where the industrial districts are absent is Calabria, apparently, the poorest economic area of the peninsula.

Even though three of the "missing regions" are located in the North, properly that part of Italy presents the highest number of IDs. In terms of geographical concentration (number of districts per hectares) the first two regions are Veneto (North-East) and Marche (Centre) with respectively values of 0.0354 and 0.0319 . The region in the South with the highest density of IDs per hectares is Campania, but the value is quite far from the previous two (Density IDs $=0.0135$ ). 
Figure 4 - Industrial Districts in Italy 2001

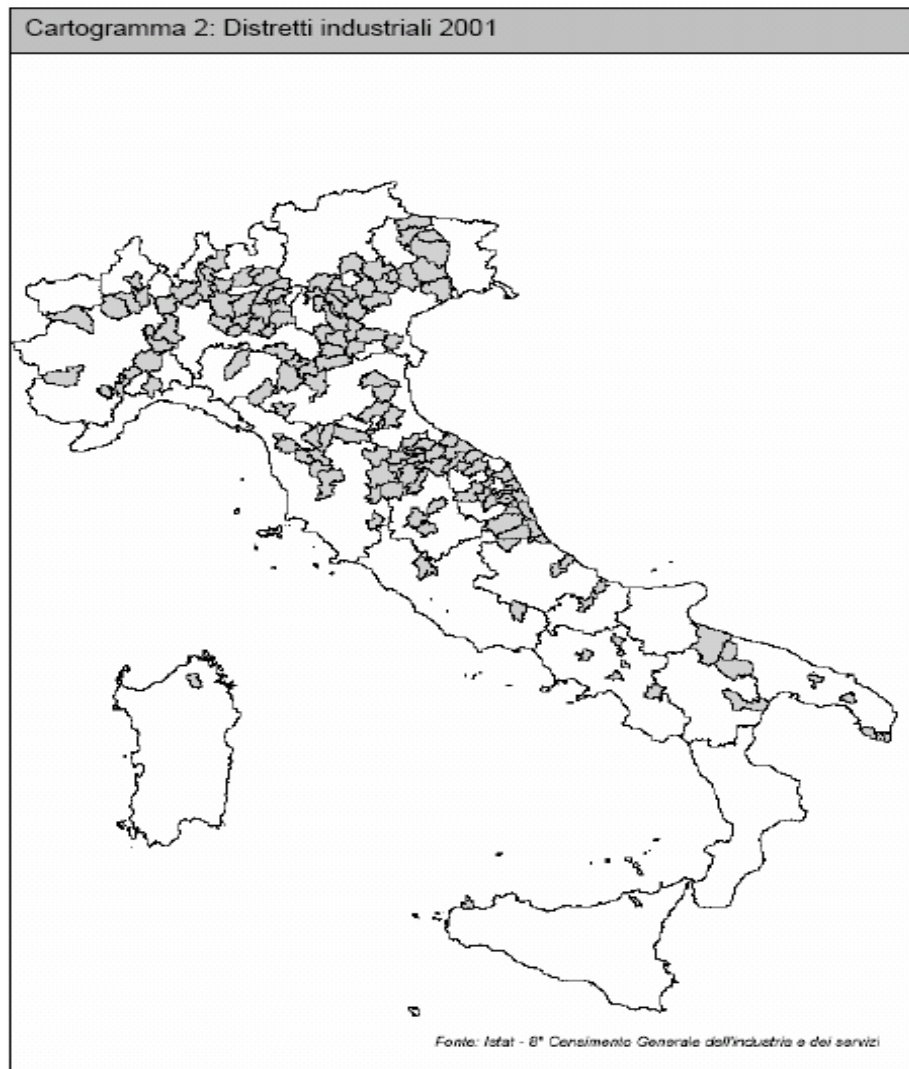

Source: " $8{ }^{\text {th }}$ General Census on Industry and Services" (2001).

Table 3 shows an example of ID drawn from the " 8 th $G$ General Census on Industry and Services" (2001). More precisely it presents the principal indicators of the industrial district of Clusone in Lombardia. 
Table 3 - Industrial Districts (example)

\section{IDs = LLS Clusone - Lombardia}

Type of Industrial District $=$ Textile

\begin{tabular}{c|c|c|c|c|c}
\hline Labour Units & $\begin{array}{c}\text { N. } \\
\text { Municipalities }\end{array}$ & $\begin{array}{c}\text { Geographical } \\
\text { Extension (Km } \\
\text { sq.) }\end{array}$ & Residents & Households & $\begin{array}{c}\text { Houses and } \\
\text { Buildings }\end{array}$ \\
\hline 13,204 & 20 & 459,78 & 37,684 & 15,261 & 35,387 \\
\hline
\end{tabular}

Source: " 8 th General Census on Industry and Services" (ISTAT 2001).

The example shows that the district of Clusone is composed by twenty municipalities with more than 13 thousands labour units working in the district area. According to the ISTAT Census ${ }^{7}$ in the district of Clusone there is an average of 3.4 workers per local unit, which intuitively indicates a very high percentage of small firms in the area. The average of the other districts is not far from that one of Clusone.

Moving the attention, for a while, to the associational activity a la Putnam (1993), the distribution of the voluntary organisations (VOs) between the North and the South of the peninsula does not seem to be much different from that one of the IDs. Figure 5 depicts the distribution of volunteers across the regions in the 2001. This clearly shows a higher concentration of associational activity in the northern regions rather than in the South. However, two exceptions have to be underlined. Firstly, the region with the highest level of industrial districts such as Marche (Centre-East) has a very low number of volunteers. Secondly, the independent province of Bolzano (North-East) has a quite large number of voluntary organisations even though it does not have any industrial district. For a more comparative analysis, table 4 shows the results of the social capital applications of the Putnam's Instruments (PI1 and PI2) and the dind. Notice that PI1 indicates the number of volunteers per 10,000 habitants and PI2 the number of VOs per 10,000 habitants. As predicted by Paldam (2000) the two ways of constructing the Putnam's instrument lead to an almost identical result since the correlation coefficient between the two proxies is 0.98 . Of course, Since PIs and DIND are all positive, increasing values of the indicators will correspond to a better scenario.

\footnotetext{
7 The table does not show this value that we have derived from the " 8 th General census on Industry and Services" (ISTAT, 2001, Tab. 16).
} 
198 | Luca Andriani

Figure 5-Distribution of Volunteers per 10,000 habitants in Italy (2001)

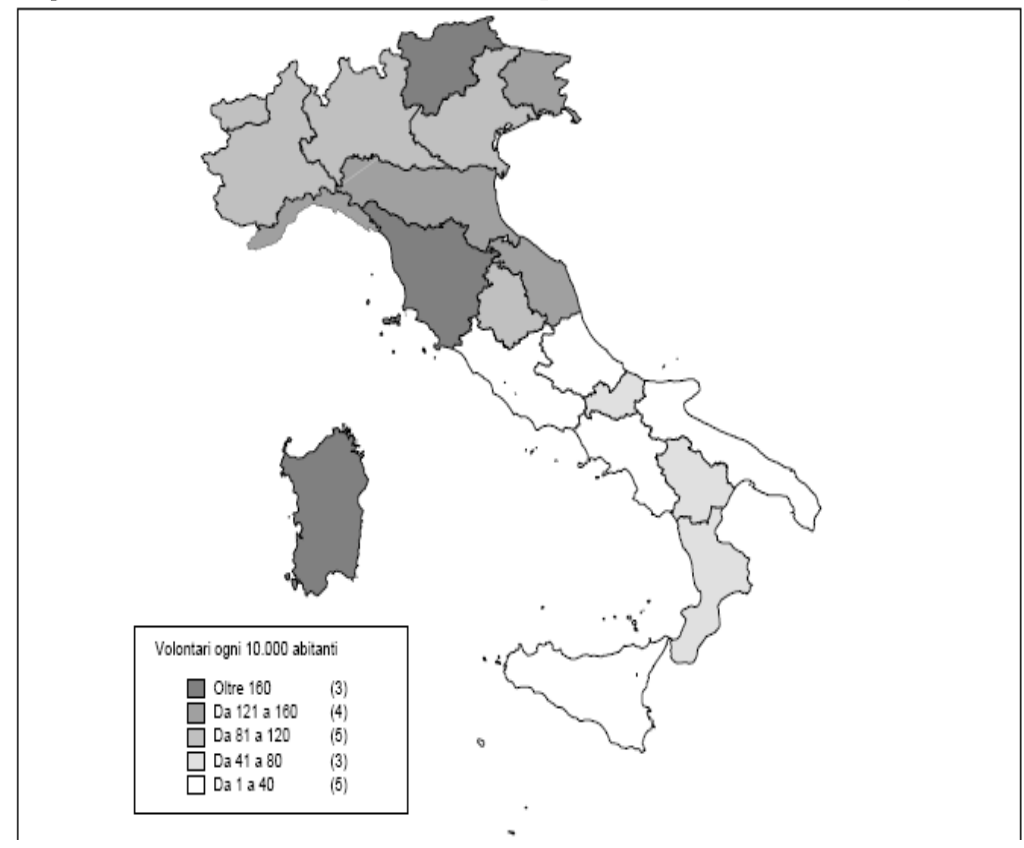

Source: "Voluntary Organisations in Italy 2001" (ISTAT 2001). 
Table 4 - Dind, PI1, PI2 and volunteer per association in the Italian Regions in 2001

\begin{tabular}{c|c|c|c|c|c}
\hline Regions & dind & N. VOs & PI1 & PI2 & $\begin{array}{c}\text { Volunteer per } \\
\text { Vos }\end{array}$ \\
\hline Pie & 0.180 & 1384 & 132.300 & 0.328 & 40 \\
\hline VdA & 0.000 & 73 & 141.500 & 0.611 & 23 \\
\hline Lo & 0.445 & 3154 & 127.000 & 0.350 & 36 \\
\hline Bo & 0.000 & 1228 & 1154.500 & 2.657 & 44 \\
\hline r & 0.237 & 332 & 244.100 & 0.698 & 35 \\
\hline Ve & 0.454 & 1907 & 134.400 & 0.422 & 32 \\
\hline FGV & 0.260 & 631 & 174.700 & 0.534 & 33 \\
\hline ER & 0.000 & 631 & 182.900 & 0.401 & 46 \\
\hline To & 0.327 & 1907 & 180.500 & 0.480 & 38 \\
\hline Um & 0.339 & 1894 & 254.400 & 0.542 & 47 \\
\hline Ma & 0.210 & 393 & 121.400 & 0.476 & 26 \\
\hline La & 0.734 & 637 & 159.500 & 0.434 & 37 \\
\hline Abr & 0.018 & 516 & 58.900 & 0.101 & 58 \\
\hline Mo & 0.049 & 130 & 103.700 & 0.405 & 28 \\
\hline Cam & 0.021 & 763 & 49.700 & 0.134 & 37 \\
\hline Pu & 0.153 & 422 & 32.000 & 0.105 & 30 \\
\hline Ba & 0.065 & 205 & 102.800 & 0.343 & 30 \\
\hline Cal & 0.000 & 363 & 69.500 & 0.180 & 38 \\
\hline Sic & 0.003 & 491 & 36.000 & 0.099 & 36 \\
\hline Sar & 0.005 & 978 & 206.500 & 0.599 & 34 \\
\hline Saut & 0.244 & 55.800 & 0.201 &
\end{tabular}

Source: Authors' reproduction on data from the Italian National Bureau of Statistics.

Table 4 shows that in the North (Piemonte, Lombardia, Bolzano, Veneto, Emilia-Romagna) the number of voluntary organisations is definitively higher than in the South (Puglia, Sicilia, Calabria, Molise). Besides, the VOs in the North involve more members per organisation. If we exclude the regions without industrial districts table 5 shows some interesting values. When we set the median for all the indicators, the only southern region above the median relative to the PIs is the region of Sardegna (Sar), while relative to the dind, the Abruzzo (Abr) is the only southern region above the median. If we compare dind with PI1 they both rank the regions of Lazio (La) and Piemonte (Pie) which do not belong to the South of Italy below the respective median region. 
Table 5-Summary statistics

\begin{tabular}{c|c|c|c|c|c}
\hline Variables & Obs. & Mean & SD & Min. & Max. \\
\hline Dind & 17 & 0.22 & 0.20 & 0.003 & 0.73 \\
\hline PI1 & 17 & 127.86 & 69.23 & 32.00 & 254.40 \\
\hline PI2 & 17 & 0.37 & 0.19 & 0.099 & 0.70 \\
\hline
\end{tabular}

Source: Author's reproduction on data from the Italian National Bureau of Statistics.

The correlation analysis between these three proxies depicted in figure 6 and figure 7 seems to add some extra interesting results and confirm this initial descriptive analysis.

Figure 6 - Italian Regions by dind and PI1

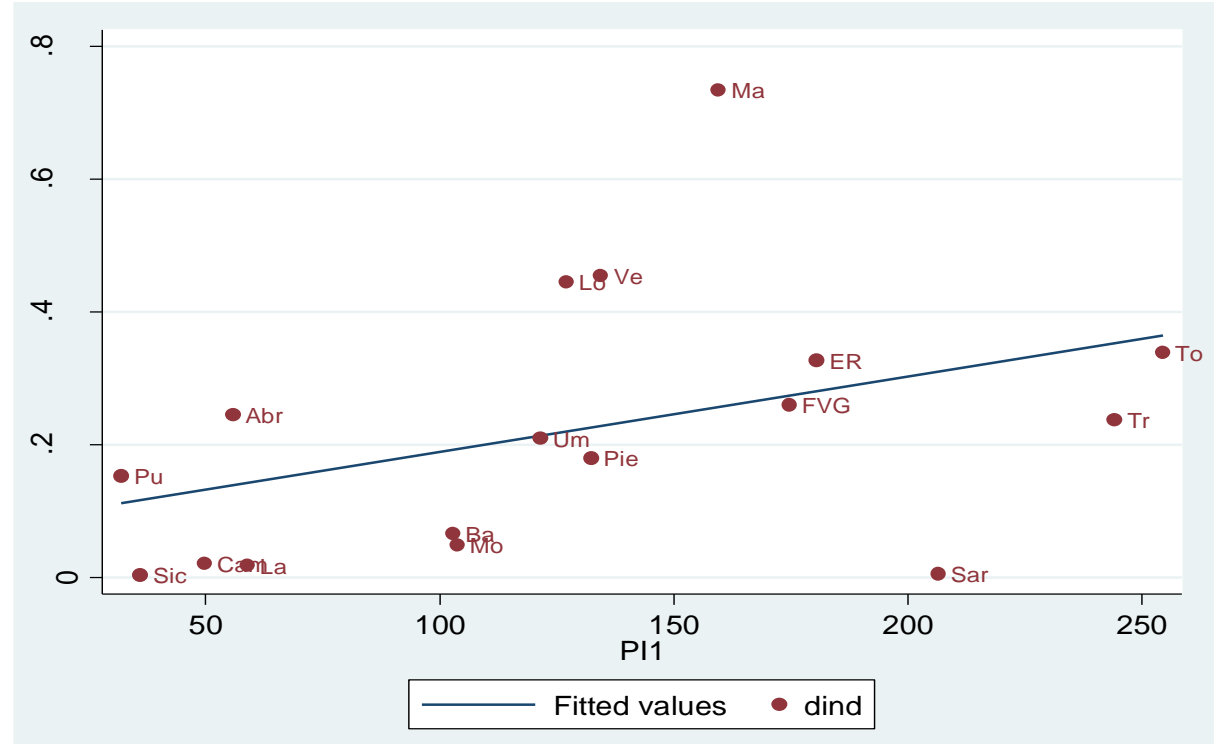

Source: Author's own production on data from the Italian National Bureau of Statistics. 
Figure 7 - Italian Regions by dind and PI2

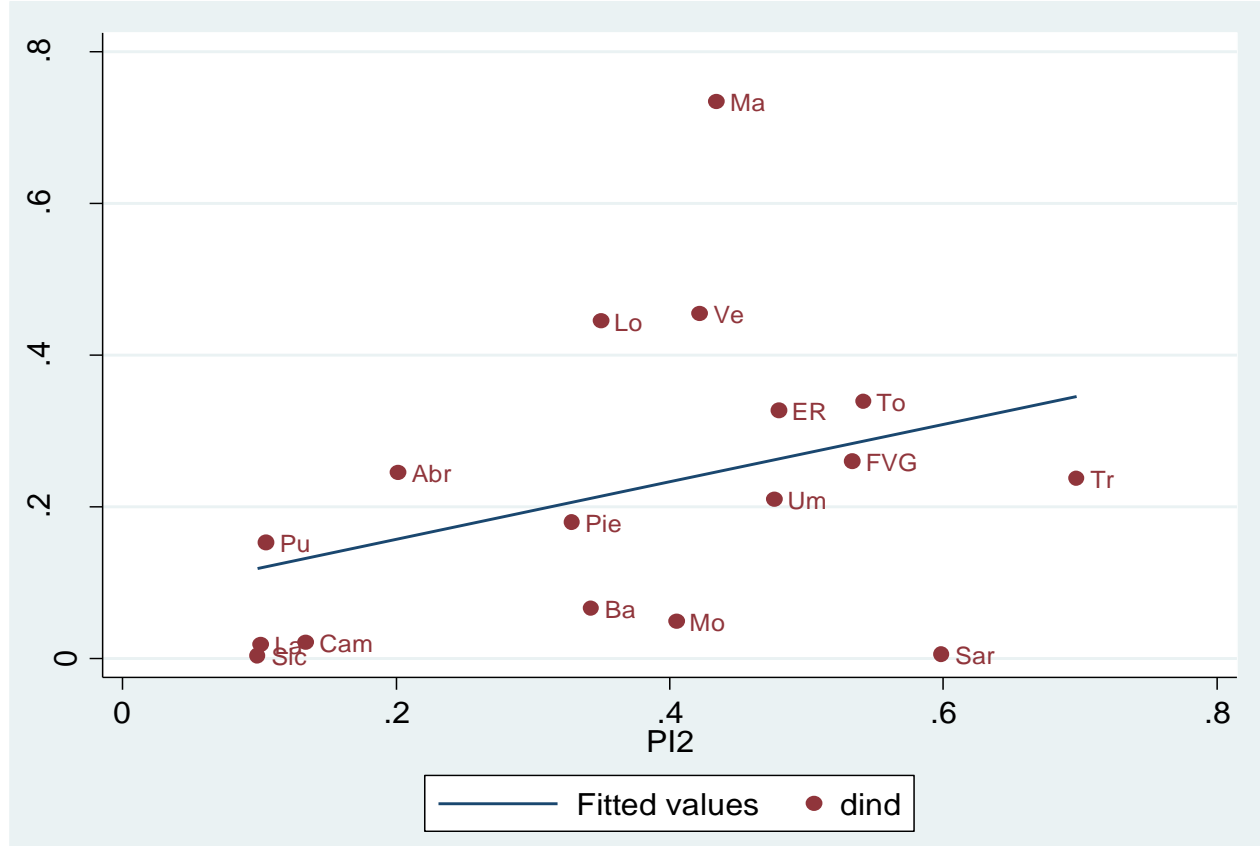

Source: Author's own production on data from the Italian National Bureau of Statistics.

The relationships between dind and the two Putnam's instruments are positive. In both of the correlation exercises the southern regions of Puglia $(\mathrm{Pu})$, Campania (Cam) and Sicilia (Sic) are in the "lower band" of the graph for both the DIND and the PI. On the other hand, the "upper band" of the graphs shows that the regions of Emilia-Romagna (ER), Toscana (To) and Friuli Venzia Giulia (FVG) are rich of these social capital indicators.

\section{Concluding Remarks}

If it is true that the deepest definition of social capital is related to the concept of "trust", then according to the "social capital dream", most of the other definitions should be derived as consequences (PALDAM, 2000). Still, the social capital dream predicts that all definitions somehow try to identify different aspects of the same phenomenon with the consequence that "all measures tap the same latent variable" (PALDAM, 2000, p. 629). This chapter argues that the intensity of the industrial district network might represent an additional proxy of social capital. The use of the term "proxy" derives from our cautiousness in the proposal of the new indicator. The multidimensional nature of social capital and the different definitions (PUTNAM, 
2000; COLEMAN, 1988; BOURDIEU, 1983 and 1986), more or less distant among each other, lead our analysis to carefully name possible alternative measures. As Paldam (2000) underlines, proxies are measures that have a distance from the definition. This, in our view, is not a sufficient reason to avoid their use at least in the operative sense. The analysis shows that dind and the Putnam's instruments seem to present similar patterns across the Italian regions, even though they cannot be considered mutually exclusive. Social capital has been recognised to be a multidimensional phenomenon and the two indicators are likely to capture different aspects of this phenomenon. Regions without industrial districts are not categorised as regions without social capital. The province of Bolzano is a quite clear example. However, we believe that the similar patterns characterising the two "measures" is challenging enough to develop further research maybe by testing whether their relationships with economic variables are significant. This might be a useful exercise in order to revisit the association between social capital and the regional economic performance in the Italian regions and not only.

- Luca Andriani é Professor Assistente da School of Business Economics and Informatics, Birkbeck University of London. E-mail: luca.andriani@bbk.ac.uk.

\section{Referências}

BAFFIGI, Alberto; PAGNINI, Marcello; QUINTILIANI, Fabio. Industrial Districts and Local Banks, Do the twins ever met? Bank of Italy, Working paper, n. 347, 1999.

BAGELLA, Michele; BECCHETTI, Leonardo; CARPENTIERI, Andrea. "The first shall be last". Size and value strategy premia at the London Stock Exchange. Journal of Banking \& Finance, v. 24, n. 6, p. 893-919, jun. 2000.

BAGNASCO, Arnaldo. Tre Italie: la problematica territoriale dello sviluppo italiano. Bologna: Il Mulino, 1977.

BOURDIEU, Pierre. The Forms of Capital. In: RICHARDSON, John. Handbook of Theory and Research for the Sociology of Education. Westport, USA: Greenwood Press, 1986. p. 241-258.

COLEMAN, James S. Social Capital in the Creation of Human Capital. American Journal of Sociology, v. 94, p. S95-S120, 1988.

Coleman, James S. Foundations of social theory. Cambridge: Harvard University Press, 1990.

DEI OTTATI, Gabi. Trust, Interlinking Transactions and Credit in the Industrial Districts. Cambridge Journal of Economics, v. 18, n. 6, p. 529-546, 1994. 
GRANOVETTER, Mark. The Strength of Weak Ties. American Journal of Sociology, n. 78, n. 6, p. 1369-1380, maio 1973.

GRANOVETTER, Mark. Economic Action and Social Structure: the Problem of Embeddedness. American Journal of Sociology, n. 91, n. 3, p. 481-510, nov. 1985.

GUERRIERI, Paolo; PIETROBELLI, Carlo. Models of industrial districts' evolution and changes in technological regimes. DRUID Summer Conference, Rebild, Denmark, jun. 2000.

GUISO, Luigi; SAPIENZA, Paola; ZINGALES, Luigi. The Role of Social Capital in Financial Development. American Economic Review, v. 94, n. 3, p. 526-556, jun. 2004.

HARRISON, Bennett. Industrial Districts: Old Wine in New Bottles? Regional Studies, v. 26, n. 5, p. 469-483, jan. 1992.

HELLIWELL, John F.; PUTNAM, Robert D. Economic Growth and Social Capital in Italy. Eastern Economic Journal, v. 21, n. 3, p. 295-307, Summer 1996.

KNACK, Stephen. Social Capital and the Quality of Government: Evidence from the States. American Journal of Political Science, v. 46, n. 4, p. 772-785, out. 2002.

KNORRINGA, Peter; MEYER-STAMER, Jörg. New Dimensions in Local Enterprise Co-operation and Development: From Clusters to Industrial Districts. ATAS Bulletin XI, The Hague and Duisburg, 1998.

LEONARDI, Robert. Regional development in Italy, social capital and the Mezzogiorno. Oxford Review of Economic Policy, v. 11, n. 2, p. 165-179, 1995.

LIN, Nan. Social Capital a theory of Social structure and Action. Cambridge: Cambridge University Press, 2001.

MARKUSEN, Ann. Sticky places in Slippery Space: A Typology of Industrial Districts. Economic Geography, v. 72, n. 3, p. 293-313, jul. 1996.

PALDAM, Martin. Social Capital: One or Many? Definition and Measurement. Journal of Economic Surveys, v. 14, n. 5, dez. 2000.

PUTNAM, Robert D. Bowling Alone: the collapse and revival of American community. New York: Simon \& Schuster, 2000.

PUTNAM, Robert D; LEONARDI, Robert; NANETTI, Raffaella Y. Making Democracy Work. Princeton: Princeton University Press, 1993.

RUSSO, Paolo Finaldi; ROSSI, Paola. Credit constraints in Italian industrial districts. Applied Economics, v. 33, n. 11, p. 1469-1477, 2011.

SABATINI, Fabio. Social Capital and Social Network: A new Framework for Measurement. University of Rome, Working Paper, n. 83, 2005.

SABATINI, Fabio. The Role of Social Capital in Economic Development. Investigating the Causal Nexus through Structural Equations Models. EconWPA, 2005.

SAXENIAN, AnnaLee. Regional Advantage Culture and Competition in Silicon Valley and Route 128. Harvard: Harvard University Press, 1996

SFORZI, Fabio. The Industrial District and the "New" Italian Economic Geography. European Planning Studies, v. 10, n. 4, p. 439-447, 2002.

SONDERSKOV, Kim Mannemar. Making Cooperation Work: Generalized Social Trust and Large N-Collective Action. 65f. Dissertação (PhD em Ciência Política), Department of Political Science, Aarhus Universitet, Aarhus, Denmark, 2008.

UZZI, Brian. Social Structure and Competition in Interfirm Networks: The paradox of Embeddedness. Administrative Science Quarterly, v. 42, n. 1, p. 35-67, mar. 1997. 
UZZI, Brian. Embeddedness in the making of Financial Capital: How Social relations and Network Benefit Firms Seeking Financing. American Sociology Review, v. 64, n. 4, p. 481-505, 1998.

WOOLCOCK, Michael. Social Capital and Economic Development: toward a theoretical synthesis and policy framework. Theory and Society, v. 27, n. 2, p. 151-208, 1998.

WOOLCOCK, Michael. The Place of Social Capital in Understanding Social and Economic Outcomes. Canadian Journal of Policy Research, v. 2, n. 1, p. 11-17, fev. 2001.

Texto recebido em 05 de março de 2015. Aprovado em 25 de março de 2015. 